\title{
Reklam Filmciliğinde Yapım Sonrası Aşamada Kurgu ve Ses/Müzik Tasarımı
}

\author{
Eda $\operatorname{Er}^{*}$
}

Ege Üniversitesi, İletişim Fakültesi, Görsel İletişim Tasarımı Bölümü, İzmir.

\begin{abstract}
$\ddot{O} z$
Hem sinema, hem televizyon hem de dijital gösterim ortamlarının yaygınlaşması ile birlikte, reklam verenlerin farklı mecralar aracilığıyla hedef kitlelerine ulaşmasında reklam filmleri önemli bir role sahip olmuştur. Reklam filminin başarısı için yapımdaki her bir aşamanın dikkatli bir biçimde planlanması ve gerçekleştirilmesi gereklidir. Başarıl bir reklam filminin tasarlanması, reklam mesajı üzerine titizlikle çalışllan yapım öncesi (pre-production) süreçten, filmin çekimlerinin ve ses kayıtlarının yapıldığ öğelerinin farklı katkılarla zenginleştirilerek bir araya getirildiğgi yapım sonrası (post-production) aşamaya dek uzanan bir süreç içinde gerçekleştirilmektedir. Reklam filmlerinin her aşamasında, yaratıcı personel reklam filminin mesajının etkili bir şekilde iletilmesine katkıda bulunmaktadır. Yaratıcı ve ikna edici bir mesaj tasarımıyla satışların attırılmasını sağlayacak etkili bir reklam filminin yapımında, gelişen dijital teknolojinin yeni teknik olanaklar sunması nedeniyle yapım sonrası sürecin önemi her zamankinden daha fazla artmıştır. Ancak Türkçe literatür içinde yapım ve reklamcılık boyutların içeren bir şekilde reklam filmciliğine özgül olarak yaklaşan çalışmalar konusunda bir boşluk bulunmaktadır. Bu nedenle, bu çalışmada literatür taraması yapılarak yapım sonrası iki temel süreci oluşturan kurgu ve ses/müzik tasarımı aşamalarının reklam filmlerinin üretimindeki yeri, önemi ve işlevi endüstri içindeki uygulama boyutuyla incelenecektir.
\end{abstract}

Anahtar Kelimeler: Reklam filmciliği, yapım sonrası, kurgu/görsel tasarım, ses/müzik tasarımı

\section{Editing and Sound/Music Design in Advertising Film Post-Production}

\section{Abstract}

Commercials have gained great importance to reach the target audience due to the rapid development and spread in the technology of cinema, television and digital media. A careful planning and realizing each stage in production is crucial for the success of the commercial. A successful commercial is designed in a process ranging from pre-production in which the message of the commercial is carefully prepared, and production in which the audio-visual material is recorded and to post-production in which all the filmic elements are assembled together creatively. The creative personnel in production team contribute to produce an effective advertising message. In the present conditions film production, and with the help of developing digital technology, postproduction has a much more decisive role in producing a creative and persuasive advertising message which will help to increase sales. Meanwhile, there is a lack of relevant literature on commercial film production, which includes both advertising and film production fields, in Turkish language. Therefore, this study aims to investigate the place, the importance and the function of editing and sound-music design processes in the post-production of commercials using literature in the field.

Keywords: Advertising film making, post-production, editing/visual design, sound/music design

\section{Gíisiş}

Bir iletişim aracı olarak sahip oldukları kendilerine özgü avantajları nedeniyle reklam filmleri, bir ürünün pazarlanması sürecinde en etkili reklam araçlarından biridir. Reklam filmleri, özellikle film yapımcılığındaki hareketli görüntü ve ses 
özelliklerini yaratıcı bir şekilde kullanılarak tasarlandıkları zaman, tüketiciyi oluşturan hedef kitleyi yönlendirme konusunda büyük bir güce sahip olmaktadır. Ancak bu gücün başarılı bir şekilde kullanılmasında yaratıcı fikir kadar bu fikrin uygulanma sürecini oluşturan yapım aşamaları ve en nihayetinde ortaya çıkan reklam filminin yapım kalitesi önem taşımaktadır. Bahsi geçen bütün yapım aşamalarının karmaşık bir yapıya sahip olduğu akılda tutularak, her bir yapım aşamasının kendi içinde detaylı bir şekilde analiz edilerek planlanması gerekmektedir.

Reklam filmlerinin yapım süreci, kaba çizgileriyle tarif edilecek olursa, reklam verenin brief vermesi ile başlamakta, ardından briefe uygun olarak yaratıcı ekibin senaryo oluşturması ve akabinde çekim senaryonun yani storyboardun hazırlanması ile devam etmektedir. Yapım öncesi aşama olarak nitelendirilen bu aşamada senaryonun reklam veren tarafından onaylanmasının ardından yapım sürecine geçilmektedir. Yapım sürecinde reklam mesajının senaryo ve storyboard ile sıkı bir biçimde saptanmış öyküsü çekilmektedir. Çekimlerin bitirilmesinin ardından sıra reklam filminin kurgulanmasina gelmektedir.

Yapım sonrası aşama olarak isimlendirilen bu süreçte reklam filmine ilişkin görsel (çekimler, fotoğraflar, vb.) ve işitsel (müzik, seslendirme, ses efekti vb.) malzemeler bir araya getirilmektedir. Bir araya getirme süreci olarak reklam filminin kurgusu ve ses/müzik tasarımı, yaratıcı düşüncenin gramerinin oluşturulduğu aşamadır; bir diğer deyişle film dilini yaratan çekimlerin bir araya getirilerek cümleye son noktanın konduğu aşamadır. Bu nedenledir ki, bir reklam filminin başarısı, yapım öncesi aşamada tasarlanan reklam mesajına uygun filmsel anlatıma ait görsel malzemelerin yapım aşamasında yaratıcı bir şekilde gerçekleştirilmesine ve bunların yapım sonrası aşamada kurgu ve ses/müzik tasarımı ile ortaya koyulmasına bağlıdır. $\mathrm{Bu}$ çalışmada bir reklam filminde mesajın oluşturulmasının son aşaması olan yapım sonrası aşamada, kurgu ve ses/müzik tasarımı süreçleri yapımcılık ve yaratıcılık yönleriyle reklamcılık ile ilişkisi bağlamında ele alınacaktır.

\section{Reklam Filmi Yapım Sürecinin Özellikleri ve Aşamaları}

Reklam filmleri sahip oldukları kimi avantajlar ve etki güçleri nedeniyle reklamcılar tarafından özellikle tercih edilen bir reklam türüdür. Kısaca tanımlanacak olursa, reklam filmi; bir kuruluşun müşterilerine, müşterisi olabilecek kimselere (olası tüketicilerine), çalışanlarına ve yetkili satıcılarına gösterilmek üzere hazırlanan; kuruluşun çalışmaları hakkında bilgi veren filmdir (Gülsoy, 1999: 12). Reklam filmleri satış yaptırmak, tanıtım yapmak ya da şirkete itibar sağlamak gibi amaçlarla yapılabilmektedir. Reklam filmlerinin diğer reklam araçları yerine tercih edilmesini sağlayan bazı nitelikleri bulunmaktadır. Dolayısıyla reklam filminin senaryosunun ve mesajının bu niteliklerin göz önünde tutulması ile hazırlanması yarar sağlayacaktır.

Reklam filmlerinin yapım sürecindeki yaratıcı personel içinde yer alan çalışma grupları açısından, başarılı bir reklam filmi üretmek için göz önüne alması gereken bazı temel noktalar bulunmaktadır: "Bir reklam filminin yapımını gerçekleştirmek için, bu gruplar ürün (konsept, karakteristikler, çekicilik, vb.), şirket (konsept, karakteristikler, tarih, vb.), tüketiciler (hedef kitle, karakteristikler, ihtiyaçlar, vb.) ve 
toplum (popülerlik, toplumsal koşullar, rekabet, vb.) hakkındaki bilgiyi analiz etmektedirler. Bu gruplar reklam öyküleri, storyboardlar ve reklam filmleri üretmek için sahip oldukları avantajlardan yararlanmaktadırlar" (Kawamura, 2016b: 119). Ayrıca ilave etmek gerekir ki, bu grupların çalışma ve analiz alanları birbirinden ayrı olmaktan çok birbirini bütünleyen ve birlikte çalışmayı gerektiren bir nitelik taşımaktadır.

Reklam filminin kendine has avantajları, kendine özgü karakteristiklerinden kaynaklanmaktadır. Reklam filmlerinin öyküleme tarzları, kurgulama teknikleri ve görsel-işitsel düzenlemeleri gibi özelliklerinden kaynaklanan; kurgu ve ses tasarımı aşamasında belirleyici olan kendine özgü karakteristikleri ise şu şekilde sıralanabilir (Kawamura, 2016b: 119):

1. Reklam filmi kısadır ve sadece ürüne ve ürünün tüketimine dair çeşitli karakteristikler arasından seçilmiş kısa bir reklam öyküsünü içine alabilmektedir.

2. Kısalığına rağmen, reklam filmi çekimi oluşturan parçalanmış bilgi öğelerinden oluşmaktadır. Seyirci, ifade edilen bu öğeleri kafasında düşünceler uyandırma potansiyeline sahip olmak için kullanmaktadır.

Reklam filmi zamandizinsel olarak kurgulandığı zaman, çekim dizileriyle yaratılan tempo ve çekimler arası ilişki seyirciye farklı imgeler sunabilmektedir.

Reklam filmi boyunca üretilmiş olan ses kuşağı, ayrıca ses ve olay öğeleri ile birlikte seyircinin zihninde düşünceler uyandırmaktadır.

Reklam filmlerinin endüstri içinde önem taşımasının yeri büyük bütçelere sahip bir reklam türü olmasıdır. "Reklam müşterileri bazen reklam filmlerine bir film stüdyosunun bir sinema filmine harcadığından daha fazla para harcamaktadırlar... Bu yüzden reklam yapım sonrası süit odaları, dolgun deri kanepeleriyle, farklı 1şıklandırmalarıyla, içindeki bilgisayar oyunlarıyla ve sürekli yiyecek ve içecek ihtiyacının karşılanmasıyla rahatlık simgesi yerlerdir. Bu süit odalara giren müşteriler reklamın özgün düşüncesinin birçok defa yeniden yazılmasının ardından geliştirilmesine kadar aylarını - bazen bir yıldan fazlasını- burada geçirmektedirler" (Cermak, 2012: 98). Bu kadar uzun sürenin harcandığı yapım sonrası mekânların çalışanlara ve müşteriye rahatlık sağlayacak şekilde lüks döşenmeleri aynı zamanda bu sürece iş uygulamaları ve yaratıcılık açısından verilen önemini göstermektedir. Büyük reklam verenlere ait büyüt bütçeli reklam filmlerinin yapım sonrası sürecinin uzun ve meşakkatli olmasının nedeni, reklam verenin pazarının da büyük ve güçlü bir rekabete dayalı olmasıdır. Bu nedenle büyük şirketler reklamlarına bazen mal ve hizmetlerinin üretim sürecinin maliyetleri ile yarışan bütçeler ayırmaktadır.

Bu kadar büyük bir reklam filmi bütçesinin dikkatli bir biçimde kullanılması gerekmektedir. Reklam filmleri yapımı yapım öncesi, yapım aşaması ve yapım sonrası aşama olarak üç aşamada gerçekleştirilmektedir. Her bir aşamada gerekli harcamalar için bütçelemenin rasyonel bir biçimde yapılması ve her aşamaya gerekli miktarda bütçenin ayrılması gerekmektedir. Bir filmin yapım sonrası aşamasının bütçesi, filmin 
büyüklüğüne göre bu aşamada kullanılacak kurgu, ses ve müzik ekibinin genişliğine ve yapım sonrası süreçlerin gereklerine göre değişmektedir. Genel bir bakış açısı sağlaması amacıyla, büyük bütçeli ve kapsamlı bir ses/ müzik tasarımına sahip bir filmin yapım sonrası süreç içindeki iş akışı aşağıdaki gibi gösterilmektedir.

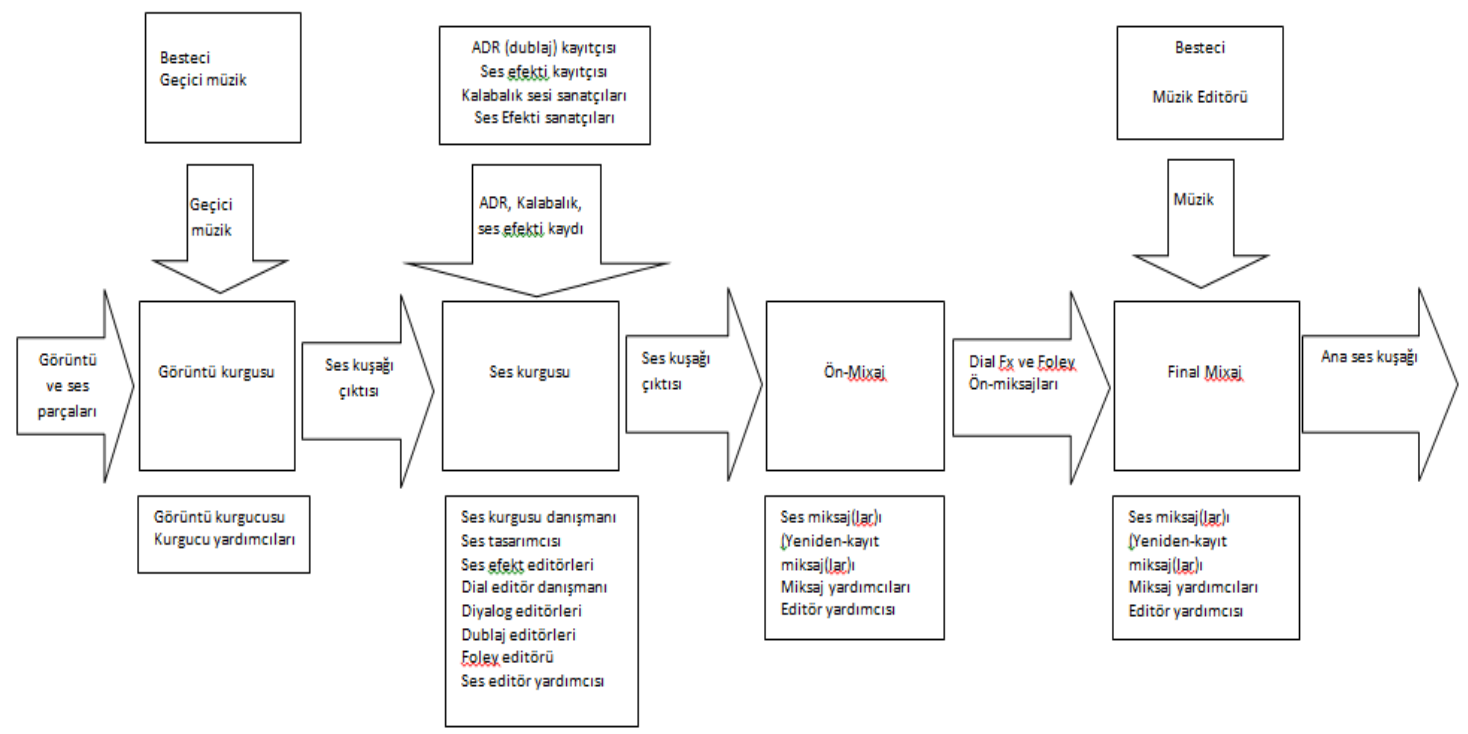

Şekil 1. Yapım Sonrası Aşamada Kurgu, Ses ve Muzik Tasarımında İş Akışı (Wyatt ve Amyes, 2005: 82)

Yukarıda görüldüğü gibi, karmaşık bir iş akış sürecini içeren yapım sonrası aşama, reklam mesajına katkısı yönünden diğer aşamalar kadar belirleyici bir önem taşımaktadır. Çünkü hem önceki aşamalarda tasarlanan düşünceler bu aşamada somut olarak gerçekleştirilmekte hem de bu aşamada yer alan yaratıcı personelin yaptığı işler daha yaratıcı ve etkili bir reklam mesajının üretilmesine büyük katkı sağlamaktadır. Kısaca tanımlayacak olursak, yapım sonrası aşama yapım öncesi ve yapım süreçlerinde yapılan tüm çalışmaların ve görsel-işitsel malzeme bir araya getirilerek yapım sonrasında eklenen malzemelerle bir arada işlendiği bir aşamadır. Reklam filmi üretim sürecinin son aşaması olarak nitelendirilen bu süreç içinde, daha önceki aşamalarda gerçekleştirilen yaratıcı çalışmaları yansıtan görsel ve işitsel bütün malzeme bir araya getirilerek reklam filminin gösterime hazır son hali ortaya konmaktadır. Buna göre yapım sonrası aşamada gerçekleştirilen çalışmalar belirleyici bir düzeyde yapım öncesinde ve yapım sırasında yapılan çalışmalara bağhıdır. Bu nedenle yapım sonrası aşama öncesinde reklam filminin hazırlanmasına ilişkin gerçekleştirilen tüm çalışmaların titizlikle yapılmış olması, yapım sonrası aşamanın başarılı bir şekilde sonuçlanması bakımından bir gerekliliktir.

Yapım sonrası aşama, filme çekilen görüntülerin kurgunun sağladığı anlatım olanakları ve görsel katkıları ile birlikte arka arkaya belirli bir sıralama içinde dizilmesinin yanı sıra, görsel ritmin yaratılmasına yardımcı olan ses ve müziklerin de miksajını içermektedir. Ayrıca hem görüntü hem de ses kuşağına efekt uygulanabilme olasılığı, bu aşamada gerçekleştirilebilecek yaratıcı çalışmalara olanak tanımaktadır. Yine bu aşamada reklamı yapılan markanın ismi ve sloganı 'packshot'a konularak 
mesajın vurgulanması sağlanmaktadır. Kısacası reklam filmciliğinde reklam mesajının üretilmesinde yapım sonrası aşama esas olarak kurgu ve seslendirme/müzik süreçlerini içermektedir. Bu şekilde hazırlanan reklam filmi daha sonra yapım şirketi tarafından ajansa ve sonrasında reklamverene sunulmaktadır. Reklamverenden onay alınmasının ardından ise, medya planlaması içinde saptanan medya kanallarına reklam filminin dağıtımı yapılmaktadır.

\section{Reklam Filmciliğinde Kurgu}

Reklam filminin yaratıcı ve ikna edici bir şekilde hazırlanmasında son aşamayı oluşturan kurgu; "çeşitli zaman ve mekânlarda filme alınan görüntülerin, senaryo[nun] ya da detaylandırılmış resimler[in] reklam senaryosuna (shootingboard) uygun olarak anlamlı bir şekilde arka arkaya sıralanmasıdır. Daha geniş bir tanımla kurgu, kamera çekimleri sonrasında elde edilen video görüntüleri arasında seçim yapmak, bunları anlatımdaki sıralara göre dizmek, sürelerini saptamak, video görüntülerinin içerik yönünden ilişkilerini göz önüne almak ve bunları belirli bir anlatıma göre düzenlemektir" (Akbulut ve Balkaş, 2007: 152-153). Dolayısıyla kurguya dair belirtilmesi gereken en önemli nokta, kurgu sürecinin fiilen yapım sonrası aşamada başlamasına karşın aslında senaryo süreciyle birlikte yapım öncesi aşamada başladığıdır. Çünkü kurgu için gerekecek olan film parçalarının çekimi ne kadar belirli bir plan doğrultusunda yapılırsa, sonuç o kadar başarılı olmaktadır.

Kurgu aşaması diğer aşamalara oranla daha fazla teknik süreç içermektedir. Fakat yapım sonrası aşamanın tamamen teknik bir süreç olarak görülmemesi gerektiğinin de altını çizmek gerekmektedir. "Yalnızca iyi bir kurgu bir filme hayat verebilir! Çeşitli çekimler, tutarlı bir öyküyü anlatacak biçimde beceriyle bir araya getirilene kadar, yalnızca bir sürü tek tek film parçasıdır. Kurgu, filmin fazlasını alır, bütün gereksiz film şeridini çıkarır. Perdedeki öyküyü seyircilerin ilgisini çekecek ve bu ilgiyi açış sahnesinden en sondaki kararmaya kadar canlı tutacak tarzda sunmak üzere, geriye kalan çekimler kesintisiz bir anlatım halinde örülmelidir" (Mascelli, 2002: 153). Kurgu aşamasında yaratıcılığı etkileyen en önemli öğe reklam filminin öyküsüdür. Reklam filminin öyküsünün hangi amaca uygun oluşturulduğu kurgu planını ve tarzını etkileyen en belirleyici durumdur. Bu bakımdan reklam filmi öykülerinin öykü tipi olarak sinıflandırılmaları ve bu sinıflandırmanın kurgu aşamasındaki yaratıcılık ile ilişkisi dikkate değer bir konudur. Reklam filmi öykülerinin sınıflandırılmasına yönelik bir analiz içinde 280 reklam filmi ele alınmış ve reklam öykülerinin değerlendirilmesi sonucunda ortaya çıan reklam filmi tipleri şu şekilde saptanmiştır (Kawamura, 2016a: 93):

1. Tedarikçi Öykü Tipi: Esas öykü yapısı tedarikçinin öyküsünü (üretim ve dağıtım, ürünün işlevi, şirket üzerindeki etki) anlatmaktadır. Bu, 'ürünün öyküsü'dür ve 'şirketin öyküsü' dür.

2. Tüketici Öyküsü Tipi: Esas öykü yapısı tüketicilerin öyküsünü (tüketim durumu, ürünün kabullenilmesi, tüketim etkisi) anlatmaktadır. 
3. Kapsamlı Tip: Bu yapı genellikle hem tedarikçinin hem de tüketicinin öyküsünü anlatmaktadır.

4. İmge Tipi: Bu yapı tüketicinin durumuna ilişkin imgeleri göstermektedir ama ürünün kabullenilmesini ve tüketim etkilerini anlatmamaktadır. Bu yapı daha çok ürünün işlevini göstermektedir.

$\mathrm{Bu}$ araştırmada ortaya koyulduğu üzere, öykü tipine bağlı olarak reklam filminin kurgu planı oluşturulmakta, çekim görselleri seçilmekte ve kurgunun zaman akışı oluşturulmaktadır. Araştırma içinde adlandırıldığ1 şekilde, kurguda kullanılan çekim tipleri, "Zaman Dizisi Tipi" çekimlerden "Üretim ve Dağıtım" çekimlerine, "Ürün İşlevi" çekimlerine, "Ürünün Kabullenilmesi" çekimlerine ve "Tüketim Etkisi" çekimlerine uzanan bir şekilde gruplandırılmaktadır. Bu çekim grupları aynı zamanda kurgu aşamasında yapılan işe genel bir bakış sağlayacak şekilde bir reklam filminin çekim tiplerini ve içeriklerini gösteren bir yapı sunmaktadır.

Yapım süreçleri açısından bakıldığında, kurgucu diğer yapım türlerinde yönetmen ile -bazı durumlarda yapımcı ile- birlikte çalışmak durumunda iken reklamcılıkta işini birlikte yapmak zorunda kaldığı insanların sayısı artabilmektedir: Reklam filminde çalışan kurgucu açısından "reklamcılık başlangıçta biraz ürkütücü olabilir. Çünkü bazen birimlerin ve kişilerin sayısı boğucu hale gelebilir. Öyle olsa da, tatmin etmeniz gereken az sayıda kişi vardır. Şirket tarafında yaratıcı yönetmen, muhasebeci ve şirket yapımcısı, güvenini elde etmek zorunda olduğunuz üç kişidir... Çoğu zaman sizin projeniz büyük bir kampanyanın bir öğesidir ve kurguda memnuniyet verecek bir estetik bu kampanyaya bağlıdır" (Button, 2002: 49). Hem bu son derece planlanmış ve organize çalışma koşullarından hem de reklam filmlerinin öykü yapısının bireysel katkıya fazla olanak tanımayan öykü yapısından ötürü, reklam filmi kurgucusu bireysel yaratıcılık konusunda daha kısıtlı davranmak zorunda kalabilmektedir.

Öykü tipine ve işlevine bağlı olarak oluşturulan senaryoya uygun şekilde çekimi yapılan görüntülerin çekim sonrasında işlenmesi süreci olarak otaya koymuş olduğumuz kurgu, günümüzde dijital teknolojinin gelişmesi nedeniyle artık neredeyse tamamen dijital ortamlarda yapılmaktadır. Bunula birlikte yakın zamanlarda bazı reklam filmleri iyi bir görüntü kalitesi elde etmek ya da farklı bir görsel etki sağlamak için $35 \mathrm{~mm}$. veya $16 \mathrm{~mm}$. film kameralarıyla çekilmiştir. Filme alınan bu görüntülerin dijital ortama aktarılması için öncelikle laboratuvarda yıkanması gerekmektedir ve kurgu aşamasında başka laboratuvar işlemlerine ihtiyaç duyulabilmektedir. Ayrıca banyo edilmiş $35 \mathrm{~mm}$. ya da $16 \mathrm{~mm}$. filmler, ya geleneksel kurgu makineleriyle kurgulanmakta ya da bu filmler telesine olarak isimlendirilen bir süreç aracılığıyla dijital ortama aktarılmakta ve bu yolla dijital kurguya hazır hale gelmektedir.

$\mathrm{Bu}$ noktada reklam filmciliğinde kullanılan kurgu sistemlerine değinmek faydalı olacaktır. Günümüzde biri çok az kullanılmakla beraber iki tür kurgu sistemi bulunmaktadır. Bunlardan ilki 'linear kurgu', diğeri ise 'non-linear kurgu' olarak isimlendirilmektedir. Teknolojik ilerlemenin dijital ortamları geliştirmesi sonucu çoğunlukla non-linear kurgu sistemi tercih edilmektedir. Her iki kurgu sistemi de 
kendi içinde kullanılan cihazların gelişmişlik düzeyine göre çeşitlilikler arz etmektedir. Ama her düzeyde de temel prensip aynı işlemektedir.

Linear kurgu VTR'lerden (Videotape Recorder) filmlerin bulunduğu kasetleri okuyan cihaz) ve onu kontrol eden cihazlarla yapılmaktadır. Bu kurgu sisteminde ses ve efektler için de ayrı cihazlar kullanılmaktadır. Linear kurguda, adından da anlaşılacağı üzere, kurguya ilk kareden başlanılmakta ve kurgu sırası senaryodaki sıraya göre olmaktadır. Non-linear kurgu türü içinde yer alan 'assemble kurgu'da görüntü ve efektlerin hepsi arka arkaya dizilerek her bir işlemin sonunda bant üzerine yeni bir time-code izi kaydedilmektedir. 'Insert kurgu' da ise kurgulanmış görüntülerin aralarında bırakılan boşluklara yeni görüntüler girilmekte ya da görüntüler değiştirilebilmektedir. Non-linear kurgu (NLE-Non-linear editing) sisteminde dijital teknoloji ve bilgisayarlar kullanılmaktadır. Non-linear sistemde prova amaçlı yapılan 'off-line kurgu' ve yayın amaçlı yapılan 'on-line kurgu' olmak üzere iki farklı tür bulunmaktadır (Akdoğan, 2008: 101-105).

Reklam filminin kurgu işlemi sırasında bir çekimden diğerine ne zaman ve nasıl geçileceği, çekimlerin sırası ve süresinin ne olacağı ve olumlu görüntüsel sürekliliğin nasıl elde edileceği olmak üzere üç temel sorunun cevaplanması gerekmektedir (Öngören, 1993: 125). Kurgu sürecinde görüntülerin hangi sıray1 takip edeceği, hangi efektler ile birlikte nasıl bir ses-müzik kuşağına uyumlu olarak yerleştirileceği gibi konular üzerine verilen kararlar reklam filminin dilinin büyük bir bölümünü oluşturmaktadır. Bu kararlar üzerinde reklam verenin bireysel talepleri, reklamın amacı ve yaratıcılık gibi konular etkili olmakla birlikte her karar, tıpkı bir dili oluşturan gramer kurallarında olduğu gibi film gramerine ilişkin kurallara da uygun olmak durumundadır. Nasıl bazı çekim ölçekleri belirli anlam yapılarına hizmet ediyorsa, kurguda seçilen görüntüler ve bu görüntülerin sıralanışları konusunda verilen kararlar da gerek açıkça gerekse ima yoluyla belirli mesajlar iletmektedir. Dolayısıyla, özellikle hem yaratıcı ekip hem de yönetmen bu kuralların bilincinde olarak filmin çekimlerini titizlikle oluşturmalıdır. Çünkü ancak bu sayede, belirlenen amaca ulaşmak için kurguda film parçacıklarının örülmesiyle anlatım yönünden güçlü ve ikna edici bir reklam filmi oluşturmak mümkün olacaktır.

Kurguya başlanırken öncelikle görüntüler izlenmekte ve bu sırada time-code tutularak kullanılmak istenen görüntüler belirlenmekte ve ardından dijital ortama aktarılmaktadır. Yine görüntülerin izlenmesi aşamasında, filmin bitmiş hali kurgucunun kafasında netleşmeye başlamaktadır. Öncelikle görüntülerin senaryo sırasına göre kurgusu yapılmaktadır. Buna 'kaba kurgu' denmektedir. Ardından ses ve görüntü efektlerinin uygulanmasına geçilmektedir. Bu süreç ise 'ince kurgu' olarak adlandırılmaktadır (Arslantepe, 2007: 141).

Reklam filmleri kısa zamanda çok şeyi anlatmayı gerektiren bir anlatı yapısına sahiptir. Dolayısıyla verilmek istenen mesajın en etkili şekilde aktarılması zorunludur. $\mathrm{Bu}$ noktada reklam filminin ritmi önemli bir kavram olarak ortaya çıkmaktadır. Reklam filminin ritmi, izleyici ilgisini yakalamada en etkili araçlardan biridir. Reklamcıların yapmamaları gereken bir hata, izleyici ilgisinin illa hızlı kurgu ritmiyle 
yakalanacağı yanılsamasına düşmeleridir. Çünkü mesajın vurgu noktalarına göre, yeri geldiğinde yaratıcı şekilde kullanılan yavaş kurgu ritmi de izleyici ilgisini çok rahat çekebilmektedir. Dolayısıyla kurguda teknik kuralların dışında, anlam yaratmak üzerine yazılmış olan tek bir kuraldan bahsedilememektedir. Buna göre "kurguda kritik olan filmin dramatik yapısını kurmak ve anlatılacak hikâyenin ne şekilde, hangi ritimle, hangi sırayla, hangi hızla anlatılacağını bulmaktır" (Canikligil, 2007: 156). Bu konuda vurgulanması gereken en önemli husus, eldeki malzemenin arka arkaya getirilmesinde seçilen tercihlerin her durumda farklı anlam oluşturabileceğidir. Çünkü iki farklı çekimin bir araya gelmesi, iki çekimin tek tek taşıdıkları anlamın ötesinde bir anlam taşıyacaktır. Yani bir diğer deyişle bütün, parçalarından daha fazla anlam ifade etmektedir.

Filmin ritmini etkileyen öğelerden en önemlisi, kurguda kullanılan geçiş efektleridir. Bu efektler filmin ritminin yanı sıra, anlatı içinde noktalama işaretleri görevini üstlenerek film dilinin oluşturulmasına katkıda bulunmakta ve filme anlam katılmasına yardımcı olmaktadır. Çünkü unutulmaması gereken nokta kurgunun, görüntüleri arka arkaya yerleştirmekten öte, anlam yaratma görevinin olduğudur.

Bu geçiş efektlerinin farklı türleri bulunmaktadır. Reklamcıya değişik olanaklar sunan 'kesme' bunlardan bir tanesidir. Basit kesmede birbiriyle ilintili görüntüler arasında geçiş yapılırken, paralel kesmede aynı sürem içinde gelişen olaylara vurgu yapılmakta, sıçrama kesmede ise akış bozularak farklı uzam ve zaman içinde atlamalar yapılmaktadır. 'Kesme'nin sertliğinden farklı olarak yumuşak ve yavaş geçiş sağlayan 'zincirleme' de de farklı uzam ve mekânlar arasında geçiş sağlanabilmektedir. Bir başka yöntem ise 'bindirme'dir. İki ayrı görüntünün aynı kare içinde üst üste gelmesiyle oluşan bu geçiş, şiirsel bir hava oluşturma gücüne sahip olduğu için özel etki yaratmak amacıyla kullanılabilmektedir. Uzak olan iki şeyi birleştiren bu yöntem, özellikle reklam filmlerinde kullanılmakta, bu yolla ürünlerin faydası karşılaştırmalı olarak (başka markalı ürün ve reklamı yapılan ürün ile yıkanan kirli gömleklerin sonuçlarının karşılaştırılması örneğinde olduğu gibi) sunulabilmektedir. 'Kararma ve açılma' yöntemi ise sahneler arasında durak işlevi görürken, sürekliliği ve anlatı akışını kesmektedir. Bir diğer yöntem olan 'silinme' de ekrandaki görüntü enine ya da boyuna hatlar şeklinde sert biçimde silinerek diğer görüntüye geçiş yapılmaktadır. Fakat reklam filmlerinde silinme yöntemi çok sık kullanılmamaktadır. Bu kadar geçiş alternatifi içinde unutulmaması gereken nokta, çekimlerde kullanılan geçişlerin iki görüntü arasındaki dramatik yapıyla ilişkili olduğudur (Yolcu, 2001b: 141-144). Elbette ki reklam filmlerdeki bu dramatik yapı da kampanyanın amacına bağlıdır. Bu efektlerin her biri, amaca uygun kullanıldığ 1 zaman anlatının etkisini arttırmaya yardimci olmaktadir.

Bu noktada kurguda geçiş efektlerinin uygulanması konusunda dikkat edilmesi gereken kurallara değinmek yerinde olacaktır. Bir reklam filmi kurgularken ritmin, mesajın ve anlatının filmin amaçlarıyla uyumlu olmasına dikkat etmek gerekmektedir. Filmin ritmini ve buna bağlı olarak anlatısını etkileyen kurgu, temel olarak dört işleve sahiptir: “1) A çekimi ile B çekimi arasında grafik ilişkiler, 2) A çekimi ile B çekimi arasında ritmik ilişkiler, 3) A çekimi ile B çekimi arasında mekansal ilişkiler, 4) A 
çekimi ile B çekimi arasında zamansal ilişkiler" (Bordwell ve Thompson, 2008:220). Görüldüğü üzere, iki görüntü arasında yapılacak olan bağlantılar çok çeşitlidir. Önemli olan hangisinin anlatıyı daha çok destekleyeceğine karar vermektir.

Nitekim Edward Dmytryk (1993: 33) de geçişlere ilişkin iki temel kural üzerinde durmaktadır: "Kural 1: Esaslı bir neden olmaksızın asla kesme yapmayın. Kural 2: Hangi kareden sonrasını keseceğiniz konusunda kararsızsanız, kısa kesmek yerine uzun kesin." Görüldüğü üzere kurgu üzerine temel bazı kurallardan bahsedilmektedir ve bu kuralların çoğu da belirli durumlarda geçerli iken, diğer durumlarda geçerliliğini yitirebilmektedir. Yani kurallar filmin geneline (öykü, yönetmen, anlatı, vs.) bağlı olarak değişiklikler gösterebilmektedir. Bu nedenle bu çalışmada, bu kuralların en genel kabul görmüş olanlarına yer vermeye çalışılmıştır.

Kurguda görüntüler bir araya getirilirken dikkat edilmesi gereken ön önemli noktalardan birisi devamlılıktır; bir başka deyişle arka arkaya getirilen yani birbirine bağlanan görüntüler arasındaki çekim ölçekleri, hareketin yönü, bakış yönü, mekansal ilişkiler, ışık gibi görsel öğeler arasındaki uyumdur. Aksi takdirde göz, atlamaların farkına varacak ve bu da filmin başarısını olumsuz yönde etkileyecektir. Dünyaca bilinen ve ünlü bir kurgucu olan Walter Murch de iki görüntü arasında uyumun yakalanmasında altı kriterden bahsetmektedir. Murch'e (2005:16) göre görüntüler arasında yapılan geçişler: "1- $\mathrm{O}$ andaki duyguya uygundur [duygu], 2- Öyküyü ilerletir [öykü], 3- Ritmik açıdan ilginç ve doğru zamanda gerçekleşir [ritim], 4- 'Gözle takip' diye adlandırabileceğimiz bir şeyi -seyircinin çerçeve içindeki ilgi odağının yeri ve hareketi ile ilgilidir- hesaba katar [göz takibi], 5- 'Düzlemselliğe' sayg1 gösterir - üç boyutlu dünyanın fotoğrafla iki boyutluya indirilmesiyle ilgili dilbilgisi (aks çizgisi sorunları vs.) [perdenin iki boyutlu yapısı], 6- Üç boyutlu dünyanın devamlılık kurallarına uyması beklenir (insanlar odada neredeler ve birbirleriyle ilişkileri nedir?) [aksiyonun üç boyutlu yapısı]." Murch'in belirttiği kuralların hepsinin altını çizdiği husus, uygulanan her geçişin bir neden doğrultusunda yapılması gerektiğidir. Özellikle çok kısa bir anlatım süresine sahip olan ve bu nedenle seyircinin daha dikkatli takip etmek durumunda olduğu bir reklam filminde, bu kuralların ihlal edilmesi hem seyircinin ilgisinin dağılmasına ya da yitirilmesine neden olacak, hem de reklamın kısa öyküsünün akışında aksamaya neden olacak ve reklamın amacına ulaşmasını engelleyecektir.

Reklam filminin kurgusu, diğer film türü kurgularına ilişkin kuralları içermekle birlikte belirli noktalarda onlardan ayrışmaktadır. Reklam filminde metin ve görüntü uyumu çok önemlidir. Reklam filmi hedef kitlenin duygularına hitap edebildiği sürece başarıyı yakalayacağından, özellikle duygusal mesajların iletilmesine özen gösterilmeli ve özellikle ürünün detaylı olarak gözüktüğü yakın çekimlerin görüntülerine yer verilmelidir. Özet olarak tekrar vurgulayacak olursak, reklam filmleri için yapılan kurgu, tanıtımı yapılan ürüne, aktarılmak istenen mesaja ve reklam filminin amacina göre şekillenmektedir. Önemli olan yapım sonrası sürecin, yapım öncesindeki kararlarla ve diğer tüm süreçlerle uyumluluk arz etmesi ve mümkün olduğunca yaratıcı uygulamalara yer verilmesidir. 


\section{Reklam Filmciliğinde Ses ve Müzik Tasarımı}

Reklam filmlerinin etkisi üzerinde en az görsellik kadar ses ve müzik öğesi de önem taşımaktadır. Bu nedenle reklam film yapımcılığının seslendirme ve müziklendirme aşaması reklam filminin yaratıcı bir reklam mesajı iletmesine büyük katkıda bulunmaktadır. Çünkü gerek seslendirmeler gerekse müzikler reklam filmini tamamlayan öğeler olarak işlev görmektedir. Reklam filmciliğinde ses kuşağının hazırlanmasında farklı yollar bulunmaktadır. "Dış ses ve müzik kuşağı, görüntünün kurgulanacağı ya da senkronize edileceği görüntüler için ya miksajı yapılmış ses kuşağı ya da miksajı yapılmış parça ses kuşağı olarak, çoğu zaman reklam şirketi tarafından yapım şirketine temin edilmektedir. Bazen de ses kuşağı tamamen yapım şirketi tarafından üretilmekte ya da miksajı yapılmaktadır" (Cudlipp, 2006: 31). Her iki tür uygulama içinde de, reklam mesajını en iyi şekilde iletecek kurguyu gerçekleştirmek üzere bütün film öğelerini bir araya getirmek durumunda olan reklam filmi kurgucusu, seslendirmede yer alan yaratıcı personel ile işbirliği yaparak reklam filmini son haline getirme işlevini yerine getirmektedir.

Seslendirme ve müzik aşamalarında reklam filmi kurgucusu, "filmleri kurgucularla, yönetmenlerle ve diğer teknisyenlerle birlikte mütalaa eden ses efekti editörleri ile birlikte çalışır ve filmin ses konusundaki ihtiyaçlarını tartışır. Gerekli sesleri kaydeder ya da ses efekti kütüphanelerinden tedarik eder. Ses kuşaklarını filme uyacak bir biçimde birleştirir. Film kurgucuları ayrıca müzik editörleri ile birlikte çalışır" (Button, 2002: 367). Bu çalışma sistemi içinde reklam filmi kurgucusunun işlevi, farklı alanlarda çalışan diğer yaratıcı personelin çabalarını reklam filminde verilmek istenen temel mesaj etrafında birleştirmektir.

Ses tasarımını tanımlamaya yardımcı olan ve ses tasarımı aracılığıyla reklam mesajının seyirciye iletilmesi işlevinin yerine getirilmesini sağlayan temel özellikler şu şekilde siralanabilir (Sonnenschein, 2001: xx):

1. Fiziksel: Bedensel, biyolojik işlevlerimizle etkileşimde bulunan mekanik, elektronik, teknik yönler,

2. Duygusal: Öykü, karakterler ve sahip oldukları amaçlar ile duygusal özdeşleşme, (gülme ve ağlama gibi) empatik tepkiler yaratma,

3. Entelektüel: İnsan etkileşimi bağlamında çoğu zaman sözel olarak iletilen yapısal, estetik düşünceler,

4. Ahlaki: Kendi kişisel tatmin ya da sağ kalma ile ilgili muhtemel seçeneklerimiz hakkında bizi uyaran etik ya da manevi perspektifler ya da ikilemler."

Başarılı bir şekilde hazırlanmış bir reklam filminde, ses tasarımı aracılığıyla bu özelliklerle ilgili yönler en az görüntüler kadar etkili, yaratıcı ve estetik bir biçimde seyirciye iletilmektedir. Böylelikle sesin ve ses ile ilgili ekipmanların fiziksel niteliklerini maksimum etki yaratacak şekilde kullanan, seyircide yaratılması arzulanan duygusal etkiyi üst düzeyde sağlayan, ses tasarımı aracılığıyla entelektüel açıdan daha derin düşünceler ortaya çıkarabilen ve bunların toplamıyla ahlaki içeriğe sahip konuları etkili bir biçimde tartışmaya açabilen bir ses tasarımı, reklam filminin 
seyirciyi psikolojik açıdan etkilemesini sağlayacak ve aynı zamanda satışların arttırılması yönünde de bir etki uyandıracaktır.

Film endüstrisi içindeki uygulama içinde ses konusu ile ilgili tartışmalar çoğunlukla kurgu aşamasına ya da filmin kurgulanmasının sonrasına kalmaktadır. Bu durum ses tasarımcisının filmin anlatımına katkısının azalmasına neden olabilmektedir. Özellikle müziğin ya da ses tasarımının ön plana çıktığı çalışmalarda, yaratıcılığı arttırmak ya da bütçe tasarrufu sağlayabilmek için ses tasarımcısına yapım öncesi aşamada danışılmasında yarar bulunan alanlar şu şekilde belirtilebilir (Sonnenschein, 2001: 215):

"Senaryo Analizi: Pahalı olan çekim zamanını ekonomik kullanmak için görüntünün yerini ses nerede alabilir? Etkiyi arttırmak maksadıyla, hangi görüntü ses için yeni bir olanak sunabilir?

Yapım öncesi planlama: Çekim yerlerinin ve ekipmanın seçimi sırasında, ses ekibinden maksimum avantaj sağlarken, 'miks masasında halletmek' zorunda kalmadan yapımdaki ses kuşağı nasıl geliştirilebilir?"

Sektör içindeki uygulamalarda pek sık görülmeyen bir durum olsa da, yapım kalitesine ve bütçesine sağlayacağı katkıdan ötürü, ses tasarımcısının projenin başlangıç aşamalarında yapım ekibine katılmasında yarar bulunmaktadır.

Reklam filmlerinde ses tasarımını incelemeye geçmeden önce, sesin hangi öğelerden oluştuğunu şu şekilde saptamak mümkündür (Cury, 2005: 129):

“Reklam filmlerindeki ses dört öğeden oluşmaktadır:

1. Dış ses: bir spiker ya da ses parçaları,

2. Müzik: Özgün müzik ya da müzik kütüphanesinden müzik,

3. Ses Efektleri: Genellikle ses efektleri kütüphanesinden bazen de reklam filmi için üretilmiş ses efektleri,

4. Eşlemeli ses: Diyalog ya da doğal ses"

Dış ses kullanımında, öncelikle reklam metninde yer alan yazılar seslendirici tarafından okunmaktadır. Çekim sırasında alınan diyalog seslerinin aksine 'seslendirme' sonradan kayda alınmaktadır. Senaryoda oyuncuların diyalogları dışında bir sesin vurgu yapması gerektiği noktalar 'dış-ses' olarak reklam filminde yer almaktadır. Filmin packshot'ında yer alan reklam sloganı da yine seslendirmeci tarafından seslendirilmektedir. Ardından bu sesler metindeki sıraya uygun şekilde, görüntüler ile eşgüdümlü olacak biçimde ses kuşağına yerleştirilmektedir. Yine bu süreçte görüntülerin müzik ile eşlemesi de yapılmaktadır.

Müzik kullanımında, reklam filminin ses tasarımında yer alan bir başka etkin öğe olarak müzikten yararlanılmaktadır. Hem filmlerde hem de reklam filmlerinde müziğe ilişkin "gösterilen filmdeki teatral hareketleri desteklemek için kullanılan müzik" (Tonks, 2006: 9) şeklinde spesifik bir tanımlama yapılmaktadır. Müzik kullanımında farklı seçenekler bulunmaktadır: Reklam filmi için telif hakkı ödemek 
suretiyle, hazır olan müziklerin (hem müziklerinin hem sözlerinin ya da sadece müziklerinin) kullanılması söz konusu olabileceği gibi, reklam filmine özel müziklerin (jingle) yaptırılması yöntemi de sıklıkla kullanılabilmektedir. Özellikle reklama özgü yapılan müzikler bazen ürünün akılda kalıcılığını arttırmakta, farklılaşmasına ve aynı kategori içinde ön plana çıkmasına yardımcı olabilmektedir. Markanın hatırlanılırlığına katkı sağlayacak şekilde yazılan sözlere ritmik, dikkat çeken ve akılda kalabilen müziklerin hazırlanması yoluyla reklam filmi, ürüne pek çok yönden katkı sağlayan olumlu bir tanıtım aracı haline gelmektedir. Bu nedenle "reklam filmi için müzik bestelemek yalnızca kısa formda (yani 30, 15 ve 10 saniye formatlarında vs.) kompozisyonlar yazmayı gerektirmemektedir. Aynı zamanda reklam filmciliği işini anlamak gereklidir" (Zager, 2015:xiii). Dolayısıyla önemli bir işleve sahip olan reklam müziğinin, reklam filminin anlatı tarzına uygun olarak hazırlanması gerektiği kadar reklamcılık amaçlarına da hizmet edecek şekilde bestelenmesi zorunluluğu vardır.

Ses efektleri kullanımında, bir diğer ses türü olarak reklam filminde yer alan 'efektler', çoğunlukla kurgu bittikten sonra filmde gereken yerlere eklenmektedir. Yani kurgudaki son işlemlerden birinin filme ses efekti eklemek olduğunu belirtmek yanlış olmayacaktır. Doğal seslerin yanı sıra ses efektlerinin de filmin tamamlanmasına, etkinin ve anlamın kuvvetlendirilmesine yardımcı olduğunu söylemek mümkündür. Ayrıca efektler sayesinde içinde bulunulan ortam hakkında da izleyiciye referanslar verilebilmekte, izleyicinin mekana ilişkin çıkarsamalar yapmasına olanak tanınmaktadır. Reklam filminin gerçekliğini arttıran bir öğe olarak ses efektleri; anlatıyı ilerletmeye, dikkati işitsel olarak çekmeye, görüntüyü işitsel olarak vurgulamaya ve uzamı düzenlemeye yaramaktadır. Ses efektlerinin diğer işlevleri arasında ise konuşmayı ve görüntüyü destekleme, sahnede bir atmosfer yaratma, süremin belirlenmesine yardım etme ve öykünün sürekliliğini sağlama sayılabilmektedir (Yolcu, 2001b:130-131). Filmi, birçok işlevi yerine getiren ses efektlerine boğmadan, onları sadece gereken yerlerde kullanarak hazırlamak gerekmektedir. Ayrıca özel bir amaç güdülmüyorsa, kullanılan efektlerin gerçekçi olmasına da dikkat edilmelidir. Aksi takdirde efektler reklam filminin inandırıcılığını olumsuz yönde etkileyecektir.

Eşlemeli ses kullanımında, çekim sırasında kayda alınan sesler kullanılmaktadır; "görüntü ile aynı anda kaydedilmiş sese 'dolaysız ses' ya da 'senkron ses' adı verilir. Bu tür sesler diyaloglardan, röportajlardan ve çeşitli gürültülerden oluşur... Görüntüyü kurgularken sistemli bir biçimde kullanılan bu sesler bütünü kimi zaman kahkahaları arttırmak yoluyla ya da arka planda bir söyleşi havası vererek sonsuz bir zenginlik katar" (Küçükerdoğan vd., 2005: 32). Çekimin yapıldığı ortama ait olarak kaydedilen diğer her türlü ses ise (doğa sesi, iç ortamdaki her türlü ses, vs.) 'doğal ses' olarak isimlendirilmekte ve içinde bulunulan ortama ilişkin bilgiler aktarma işleviyle bir tür referans aracı görevi görmektedir.

Dijital kurgu olanaklarının gelişmesi kurgucuya sayısız ses kuşağı ile çalışma fırsatı vermektedir. Genellikle oyuncuların sesleri, ses efektleri, dış-ses ve müzik ayrı ayrı ses kuşaklarında kurgulanmaktadır. Bu, temiz bir time-line'da çalışma fırsatı tanıyarak karışıklıkların önüne geçilmesine yardımcı olmaktadır. Aynı zamanda farklı 
ortamlarda alınmış ses kayıtlarının (dolaysız ses, seslendirme, ses efektleri, müzik, vs.) ses seviyelerinin ayrı ayrı ayarlanarak tek bir düzeye çekilmesine de olanak tanımaktadır. Bu aşamada dikkat edilmesi gereken en önemli nokta, görüntü ve ses kuşakları arasındaki uyumun sağlanması gerekliliğidir. Öte yandan görüntü devamlılığı şartında olduğu gibi, seste de devamlığın sağlanması zorunluluğu bulunmaktadır.

Yukarıda belirtmiş olduğumuz gibi, bir reklam filminde hepsinin ya da birkaçının yer alma ihtimali olan sesler arasında; oyuncuların diyalogları, metnin filmin üzerine okunduğu dış-sesler (voice-over), çekimler sırasında ortama ait olan ve kayda giren doğal sesler, ses efektleri ve müzikler yer almaktadır. Bu seslerin kayıt süreci iki farklı şekilde gerçekleşebilmektedir. Bazıları (doğal sesler ve bazen diyaloglar) çekim sırasında kayda alınıp kullanılabilmekte, diğerleri ise (dış sesler, müzik ve bazen diyaloglar) sonradan seslendirme yoluyla ses kayıt ortamina aktarılarak kaydedilebilmektedir. Sonradan seslendirme sürecinde, seslendirme konusunda her türlü müdahaleyi gerçekleştirmek mümkündür. Ama yapım aşamasında kaydedilen sesleri bir daha aynı ortamda elde etme şansı bulunmamaktadır. Yine de yapım sonrası süreçte bu konuda bir takım düzeltici işlemler gerçekleştirilebilmektedir. Örneğin reklam filminin metnine yeni bir sözcük eklenecekse, "dudak devinimlerini değiştirebilir miyiz? sorusunu 'evet, hem de düşünemeyeceğiniz esneklikte' biçiminde yanıtlamak olanaklıdır. Reklam filmine sözcük eklenecekse, başka kişi ya da nesneleri ekrana getirerek sözcüklerle oynayabilirsiniz" (Yolcu, 2001a: 405). Bu uygulamada kurgucunun yaratıcı becerisi ve ses tasarımcısının katkısı, tek bir sözcük ya da birkaç yeni sözcük için yeniden set kurulmasına ihtiyaç bırakmayarak yapım bütçesinin artmasını önlemektedir. Bu açıdan kurgu aşaması hem çekim aşamasındaki eksikliklerin yaratıcı çözümlerle giderilebileceği hem de reklam mesajına yaratıcı yeni katkıların yapılabileceği bir aşama olarak da değerlendirilebilir.

Reklam filminin ses tasarımında formatın belirleyici olduğu ve reklamcılık amaçlarının en fazla dikkate alınmasının gerektiği müzik "ses imzaları" ya da "ses amblemleri" aracılığıyla yapılan "ses markalaması" ya da "sonic markalama"dır. Reklam filmlerinin ses tasarımda kullanıldığı anlamda "amblemler kısa müzikal formatlardır ama cıngıllarla kıyaslayacak olursak, amblemlerde melodi yoktur ve çoğu zaman daha kısadır... Amblem, sahip olduğu sesi ve logo ile senkronize edilmesiyle ayırt edici bir nitelik edinmektedir" (Graakjaer, 2015: 119). Bu türden ses markalamalarında logo ile uyumlu bir biçimde hazırlanmış müziğin tarzı da belirleyici bir önem taşımaktadır.

Bu konuda yapılan araştırmalarda ortaya çıkan sonuçlara göre, bir markayı temsil edecek müzik türü yaratacağı etki ve sahip olduğu çağrışımlar nedeniyle seçilmektedir. "Örneğin, punk ve hip-hop daha çok bireysel bağımsızlığa değer vermekle ilişkilendirilmektedir, oysa country müzik ya da Alman folk tarzı daha çok aileye değer vermekle ilişkilendirilmektedir. Alman folk tarzı geleceğe duyulan iyimserlik ile ilişkilendirilirken, punk daha fazla kötümserlik ile özdeşleştirilmektedir" (Shevy ve Hung, 2013: 325). Her müzik türünün belirli duygu ve düşüncelere hitap 
eden tarzıyla belirli hedef kitlesine sahip olması, reklam filminin hedef kitlesine uygunluk taşıması durumunda seçilen türdeki müziğin ya da ses ambleminin etkisini de arttırmaktadir.

Tony Thomas'a göre film müziği iki önemli konuda filme katkı sağlamaktadır. Öncelikle atmosfer yaratılmasına yardımcı olmakta, ikinci olarak filmin tansiyonunu belirtmekte, güçlü ya da zayıf bir etki yaratmak amacıyla kullanılmaktadır (Akt: Erdoğan ve Solmaz, 2005: 60). Michael Rabiger ise, müziğin işlevleri hakkında şu yorumu yapmaktadır (Akt: Corner, 2005: 244):

- "Müzik seyirciye sahte duygu zerketmemelidir,

- Müzik seçimi karakterin ya da öznenin iç yaşamına giriş sağlamalıdır.

- Müzik seyircinin gösterilmekte olan şeyi araştırmasını sağlayacak duygusal bir düzeye işaret edebilmelidir."

Rabiger'in belgesel filme ilişkin olarak belirttiği bu bilgiler reklam filmi için de geçerlidir. Hem Thomas'ın hem de Rabiger'in ifade ettikleri gibi, film müziği özellikle konuşmanın olmadığı çekimlerde psikolojik durumları aktarmada etkili olmaktadır. "Her müziğin özünde iletişim bulunmaktadır, ister kişisel bir ifade olsun, ister manevi mesajlar olsun, ister siyasi ikna ya da ticari çekicilik olsun... Müzik yalnızca filmlerin ses kuşaklarının müziklendirilmesinde bariz bir rol oynamamaktadır, film müziği aynı zamanda ses tasarımcısına durumun içyüzünü gösterebilecek sözel olmayan bir dildir. Müziğin gelişimini takip ederek, müziğin duyguları açığa çıkarma ve evrenimizi düzenleme yeteneği arasındaki ayrımı gözlemleyebiliriz" (Sonnenschein, 2001: 101). Müziğin kendine özgü bu gücü, reklam filminin mesajına işitsel ve duygusal bir boyut katarak iletilmek istenen mesajın duygusal etkisini arttırmaktadır.

Reklam mesajının ağırlıklı olarak müzik kullanılarak verildiği ve ürün için özel beste yapıldığ 1 durumlarda, reklam filminin kurgusu tamamen bu müziğe uygun bir biçimde tasarlanmaktadır. Özellikle müziğin ön planda olduğu reklam filmlerinde, "müziğin reklamcılık içinde oynadığı rol üzerinde dikkatlice düşünülmelidir. Çünkü müzik dikkati çekmekte, üstü örtülü ya da açık mesajlar iletmekte, duygular üretmekte ve bir insanın bilgiyi muhafaza etmesini sağlamaktadır" (Zander, 2010: 128). Görsel imgeler ile müziğin karşılıklı ilişkisi içinde, reklam müziği bazen anlatımın ağırlıklı öğesi haline gelmekte ve kimi örneklerde reklam filminin görsel ağırlığı ile etki bakımından yarışarak müşterilerin ikna edilmesinde ve satın alma davranışına yöneltilmesinde büyük etki uyandırmaktadır.

Bunların dışında reklam filmi müziği ürüne vurgu yaparken, aynı zamanda duyguları harekete geçirmeli ve görselliğin ifadesinde eksik kalan duyguları aktararak izleyicilerin belirli bir duygu yoğunlaşması yaşamalarını sağlamalıdır. "Eğer reklam filminiz metin ya da açık gerçekler yerine duygusal tepki üzerine kurulmuş ise, müzik sizi ayrı bir ikna dünyasına yönlendirebilir" (White, 1986: 193). Bu sayede izleyici ile ürün arasında duygusal yönden yakın bir bağ kurulabilmektedir. Bu bağın kurulmasında tarihsel bir atmosfer sağlayan dönem müzikleri etkileyici sonuçlar ortaya çıkarmaktadır. Bu nedenle reklam filmlerinde müzik konusunda çalışan 
“yaratıcı insanlar çoğu zaman belirli bir zaman dönemine ya da özgül bir stile öykünen müzik talep etmektedirler. Bestecilerin karşılaştığı ana sorunlardan birisi stilistik otantiklik sağlamaktır. Bu konudaki amaç elde edilemeyince, bu durum çok belli olmaktadır; ne yazık ki, reklam filmlerinde sahte sesler oldukça yaygındır" (Zager, 2015: 39). Doğal olarak, dönemin otantik havasını yakalayamayan bir müzik reklam mesajının sağlamak istediği duygusal atmosferi oluşturamayacağı için, reklam mesajının ikna edici bir şekilde iletilmesini de sağlayamayacaktır.

Sayıldığı gibi birçok avantaj sağlama işlevine sahip olan müzikleri doğru ve etkin bir şekilde kullanan reklam filmleri, hem reklam filminin mesajını daha güçlü bir şekilde vurgulamakta hem de bunu seyirciyi eğlendiren bir şekilde yapmaktadır. Ayrıca kendi görselliğine müziğin seyircinin zihninde yarattığ görselliği ekleyerek reklam mesajının daha kalıcı olmasına yardımcı olmaktadır. Hiç kuşkusuz bu temel özellikler yalnızca iyi bir kurgu ve ses/müzik tasarımı personelini gerektirmemektedir. Bu noktada onların yaratıcı bir şekilde bu özellikleri sağlayacak bir kurgu yapmasına olanak tanıyacak iyi bir besteci de kilit önem taşımaktadır.

\section{SONUÇ}

Reklam filmleri görüntüyü ve sesi bir arada kullanmaları ve bu özellikleriyle tüketiciyi satın alma davranışı yönünde ikna edici bir biçimde etkileyen başarılı birer araç olmaları nedeniyle reklam verenler tarafından sıklıkla tercih edilmektedir. Bu nedenle tüketiciye vaat edilen faydanın sunumunda, ürünün kullanım şekli ve alanlarının gösteriminde reklam filmlerinin büyük avantajı bulunmaktadır. Reklam mesajının hedef kitle üzerinde etkili olabilmesini sağlamak için söz konusu fikri doğru şekilde hayata geçirecek yapım uygulamaların gerçekleştirilmesi gerekmektedir. Satışları arttıracak ya da şirkete itibar sağlayacak bir reklam filminin üretim sürecinde, yapım öncesi, esnası ve sonrası aşamaların ayrı ayrı detaylı bir şekilde planlanması ve dikkatli biçimde gerçekleştirilmesi önem taşımaktadır. Çoğu zaman reklam mesajlarına çekim ölçekleri, 1şık ve aydınlatma türleri, kurguda (görüntülerde, seslerde, müziklerde, efektlerde ve geçiş türlerinde) yapılan tercihler gibi öğeler aracılığılyla alt anlamlar kazandırılmakta ve bu yolla tüketicinin bilinçaltı güdümlenmeye çalışılmaktadır. Bu nedenle reklam filmini oluşturan her öğe belirli bir amaç doğrultusunda, bilinçli olarak ve ustaca gerçekleştirilmiş yapımcılık uygulamalarıyla üretilmelidir. Reklam filmi hazırlanırken yapım ekibinde yer alan yaratıcı personelin çalışmaları mesajın başarısını etkilediği için, yapım sürecinin her aşamasında yer alan ekip üyelerinin görevleri ve işlevleri üzerine doğru ve tam bir bilgiye sahip olunması önem taşımaktadır. Reklam filmi yapımcılığı, genel olarak sinema ve televizyon için film üretimi içinde bir alan olarak görülmesi nedeniyle çoğu zaman bu literatür içinde ele alınmaktadır. Ancak reklam filmlerinin reklamcılık uygulamalarıyla ilgili bir yanı da bulunduğu için, reklam filmi yapımcılığını her iki bakış açısıyla ele alan çalışmaların yaygınlaşması yarar sağlayacaktır. 


\section{KAYNAKÇA}

Akbulut, N.T. ve Balkaş, E. (2007). Televizyon Reklâm Filmi Yapımı, İstanbul: Beta Basım.

Akdoğan, S. (2008). El Yapımı Sinema, Ankara: Medya Akademisi Eğitim Serisi:2.

Arslantepe, M. (2007). Bir Film Çekmek ve Masaüstü Filmciliğe Giriş, İstanbul: Beta Yayınları.

Bordwell, D. ve Thompson, K. (2008). Film Sanatı. (E. Yılmaz ve E. S. Onat, Çev). Ankara: De Ki Basım Yayım Ltd.

Button, B. (2002). Nonlinear Editing: Storytelling, Aesthetics, and Craft. Kansas: CMP Books.

Canikligil, İ. (2007). Dijital Video ile Sinema, İstanbul: Pusula Yayınları.

Cermak, K. (2012). How to Get into and Survive Film, Advertising and TV Postproduction: The Alternative Guide. Londra: Clouds And Ivy Ltd.

Clark, B. ve Spohr, S. (2013). Guide to Postproduction for TV and Film: Managing the Process. Massachusetts: Focal Press.

Corner, J. (2005). Sounds Real: Music and Documentary, New Challanges for Documentary (A. Rosenthal ve J. Corner, Ed.). Manchester: Manchester University Press.

Cudlipp, P. (2006). Commercials, Film Business: A Handbook for Producers (T. Jeffrey Ed.). New South Wales: Allen and Unwin.

Cury, I. (2005). TV Commercials: How to Make Them: Or, How big is the Boat?. Burlington: Focal Press.

Dmytryk, E. (1993). Sinemada Kurgu. (Z. Özden, Çev). İstanbul: Afa Yayınları.

Erdoğan, İ. ve Solmaz, P.B. (2005). Sinema ve Müzik: Materyal Satış ve Bilinç Yönetimi Iç̧in Bilişsel ve Duygusalın Oluşturulması. Ankara: Erk Yayınları.

Graakjaer, N. J. (2015). Analyzing Music in Advertising: Television Commercials and Consumer Choice. New York: Routledge.

Gülsoy, T. (1999). Reklam Terimleri ve Kavramları Sözlü̈̆̈̈. İstanbul: Adam Yayınları.

Kawamura, Y. (2016a). A Viewing Experiment on the Effects of Advertising Story, Journal of Robotics, Networking and Artificial Life, 3(2):92-95. Paris: Atlantis Press.

Kawamura, Y. (2016b). An Attempt of the Commercial Film Production Support System Based on the Image Rhetoric of Commercial Film, Computational and Cognitive Approaches to Narratology, (T. Ogata, T. Akimoto, Ed). Pennsylvania: Hershey.

Küçükerdoğan, B., Yavuz, T., Zengin, İ. (2005). Video ve Film Kurgusuna Giriş, İstanbul: Es Yayınları.

Mascelli, J. V. (2002). Sinemanın 5 Temel Öğesi. (H. Gür, Çev). İstanbul: İmge Yayınları.

Murch, W. (2005). Göz Kırparken. (İ. Canikligil, Çev). İstanbul: İstanbul Bilgi Üniversitesi Yayınları 104.

Öngören, M. T. (1993). Senaryo ve Yapım: Yapım Tekniği. 3.kitap. İstanbul: Alan Yayınları.

Shevy, M. ve Hung, K. (2013). Music in Television Advertising and Other Persuasive Media, The Psychology of Music in Multimedia, (S. Tan, A. J. Cohen, S. D. Lipscomb ve R. A. Kendall, Ed.) Oxford: Oxford University Press. 
Sonnenschein, D. (2001). Sound Design: The expressive Power of Music, Voive and Sound Effects in Cinema, Michigan: Michael Wise Productions.

Tonks, P. (2006). Film Müziği, (A. Sivas, Çev). İstanbul: Es Yayınları.

White, H. (1986). How to Produce Effective TV Commercials. Illionis: NTC Business Book.

Wyatt, H. ve Amyes, T. (2005). Audio Post Production for Television and Film: An Introduction to Technology and Techniques. Burlington: Focal Press.

Yolcu, E. (2001a) 'İyi’ Bir Reklam Filminde Aranması Gereken Özellikler, İstanbul Üniversitesi İletişim Fakültesi Dergisi, Sayı 11: 399-408.

Yolcu, E. (2001b). Televizyon Reklamcllığı: Sinemanın Etkisinde Düşünsel ve Görüntüsel Yaratım Öğgeleri Açısından. İstanbul Üniversitesi Yayın No: 4302. İletişim Fakültesi Yayın No:13. İstanbul: Emek Matbaacılık.

Zager, M. (2015). Writing Music for Commercials: Television, Radio and New Media. Lanham: Rowman and Littlefield.

Zander, M. F. (2010). Music in Advertising: Effects on Brand and Endorser Perception, Advances in Advertising Research (Vol. 1): Cutting Edge International Research. (R. Terlutter ve S. Diehl, Ed.), Wiesbaden: Gabler Verlag. 